\title{
Lean Concept in Transmitter Production
}

\author{
Miloš Vorkapić1,*, Siniša Minić ${ }^{1}$, Bogdan Popović1 ${ }^{1}$, Predrag Poljak ${ }^{1}$ \\ ${ }^{1}$ University in Belgrade, IHTM-CMT, Belgrade, Serbia \\ ${ }^{2}$ University in Priština- Kosovska Mitrovica, Serbia
}

The algorithm for providing improvement of production processes in the company of small-batch type of production has been intrduced in this paper. Lean manufacturing or concept in the process of improving production is used increasingly. However, the concept is designed for large enterprises. The process of production transmitters or the possibility of implementing the concept according to the known principles has been analyzed in this paper. Credibility of the algorithm is reflected in giving recommendations on how to eliminate the short comings in the production process through transmitters: regular movement of employees, regular sequence of operations, products design, and cooperation with customers, reducing inventory and control introduction in all stages of the process. The production process with the implemented process of reproduction makes an integral part of Lean concept. The paper gives an example of how to save on material and other resources in the company arising as large losses in the production process.

\section{Keywords: Transmitter, Algorithm, Waste, Remanufacturing, Lean concept, Company, Control,}

\section{INTRODUCTION}

Customers select products from all over the world, so that struggle is not on the state any more but on a world-scale. The current trends in production are related to the increased automation, control of production processes and researches. Customers are getting more and more demanding, so manufacturers must offer products that are high quality, functional, ergonomically designed, while delivery times are increasingly reducing. Improvement of the production process has become an imperative over competition. Customers must submit detailed specifications, so a manufacturer can design and make a product that will meet their needs. [1]. This the same process applies for changes on existing products as well as for changes to the new products. Many manufacturers prefer on consumer to determine the required functionality arising from the product, as well as other critical ecological attributes (size, electrical constraints and vibrations). It is very important, which strategy the company will implements in order to meet its needs and marketplaces. An attempt was made in this paper to point out the importance of Lean concept in the production process and reproducing in the case of production of pressure transmitter. Reducing waste in the very process of making new products or direct use of used components certainly become imperative for business of small and medium-sized enterprises in Serbia.

\section{DIAGRAM OF FLOW MATERIALS}

The production process represents transformation process of inputs to the outputs values. Generally, there are three basic types of inputs: materials, energy and other factors (water, tools, supplies, information) [2-4]. Output values in the process of transformation, which are the most common: the final product, material losses, energy loss, wasted time, wasted movement, wasted inventory due to overproduction, customer delays, waiting for approvals, unnecessary steps, duplication of efforts, and errors (new terminological approach: product and waste) .

In the Fig. 1, is formed a diagram of flow materials in the production process [5-8]. This refers to sustainable production in the field of acceptable sustainable development of small and medium-sized enterprises (hereinafter SME) [9-12]. Diagram of flow materials implies an active participation of the management in optimizing of all activities, from reducing the cost of input values to the monitoring, measurement and control of input, intermediate and output elements. The production process consists of three sub-processes (see figure 1): production preparation or preparatory stages, production process and the end of production process [13].

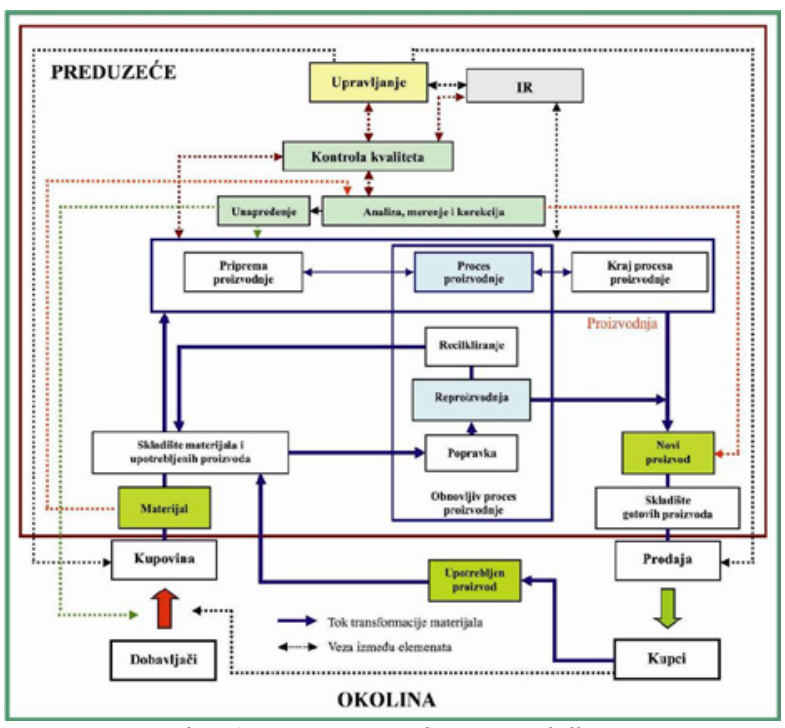

Fig. 1. Diagram of material flow

Managing of production elements is done through quality control that in itself includes: 1) analysis, measurement and correction of parameters of outputs and 2) improvement of input parameters (see Fig. 1) [7]. 
In this regard, in the process of renewable production should pay attention to the organization of production process through [14]: reducing the consumption of energy and resources, reducing the use of toxic materials; the use of materials of good characteristics and quality, the possibility of upgrading and repair.

The material is purchased from a supplier/vendor, then is carried out the entrance control of materials and eventually is stored in the warehouse. Then follows the process of production or process of transformation of materials into final product. The control of a new product is done at the exit, and after controlling the finalized product is stored in a warehouse. Remanufacturing as a strategy of renewable production system is implemented in the diagram of flow.

System is being considered satisfying if there is a demand for manufacturing and remanufacturing (see Figure 1) [15]. Such a system includes the purchase of products from customers, then their storage and later on using in the process of remanufacturing.

However, diagram of process flow provides space for Lean concept which includes in itself operations of manufacturing and remanufacturing,leading to the reduced production time and significant reduction of inventories. [16]. By applying remanufacturing (or reuse of products) in researching [17] the authors suggested that it can be saved up to $85 \%$ of the products weight, and it takes $80 \%$ less energy for the realization of the final products.

Many companies have become successful by applying remanufacturing. There are following adventages of remanufacturing, that are emphasized in the literature [18-19]: 1) companies using the used products have reduce its expenses (price of product and disposal is reduced), 2) implementation of remanufacturing itself in the terms of marketing represents a strategy for increasing profits, 3) in the process of remanufacturing is used specialized equipment (comes up to the product improvement, reduces disposal costs), 4) tools are optimized due to disassembling and assembling 5) remanufacturing provides stability in investments and in business of enterprises (increases control of markets, open up new job opportunities, expertise of designers comes to the fore) and 6) there is independence from suppliers/vendors.

\section{LEAN CONCEPT}

Lean concept (hereinafter LC) is a system created for the customer, where the basic idea is optimization of the production process, production of cheap products in time and and with best quality[20]. The principle is to produce just what is needed for the next stage or operation under the condition that previous operation ends and begins next one. LC offers a set of tools and techniques as well as a systematic approach to eliminate "waste" in the production process with an increase in production flexibility [21].

Waste (Eng. Waste) can be treated as: loss, expense ,uselessness, needlessness. It represents any activity in the company, which does not contribute to the final value of the product and thereby spends certain resources .

The Lean principles [22]:

1. Identify value - according to the authors 'Value' is defined as a capability provided to the customer at the right time at an appropriate price as defined in each case by the customer. Specify what creates value from the customer's perspecticve. Value can be only defined by the ultimate customer;

2. Map the value stream - LC requires extremely accurate and detailed manufacturing procedures and it means: condition of materials, the time for preparation, continuing operations and the result of the activities conducted by the employee in the course of work;

3. Create flow (make the value flow without interruptions) - indicates that in the manufacturing process must be eliminated any interruption, detour and waiting; Flow is defined as the progressive achievement of tasks along the value stream so that a product proceeds from design to launch, order to delivery and raw materials into the hands of the customer with no stoppages, scrap or backflows.

4. Establish pull (Pull system) - strategic decision that points to produce only what the customer wants and when the cutomer wants it (the case where the customer dictates the production);

5. The quality of the input/source - Test out your process, collect data on how well it is working, highlight and eliminate errors, and seek continuous improvements in value;

6. Seek perfection - the production errors and losses must constantly be removed in production. Strive for perfection by constantlly removing waste.

Operational excellence means eliminating waste from processes continuously. By reconfiguring work so that value flows to customers unimpeded, high-performing companies free up resources and capital, boost return on assets, and set the stage for sustainable growth.

In LC employees are constantly learning, so if you achieve the maximum at one workplace, transferred to another post, etc. In this way, employees become motivated to work, and the production process is constantly improving.

\section{LEAN CONCEPT IN SMALL AND MEDIUM-SIZED ENTERPRISES}

Application of LC in SMEs primarily dependents on key customers. [23]. LC has been successfully implemented in many large companies (hereinafter LC), but there are still weak and insufficient documentary evidence of its use in SMEs [24-25]. SMEs need to change complete organization of the company through the use of tools and techniques in order to achieve higher quality and greater productivity, but also to carry out a proper planning before starting the manufacturing process [26-38].

According to the source [29], medium-sized enterprises (ME) have a greater tendency to implement LC (over 50\%) than small companies (SC). Problems for the introduction of the LC in SC can be justified: the lack of skilled labor, lack of funding and the presence of a large number of products.

The guidelines are given in the literature [30] by which should be eliminated deficiencies in business of SMEs and can be beneficial for domestic companies:

1) Dealys in manufacturing process- Most delays occur as a consequence of interrupting or waiting in 
the work. Due to bad planning of production, lack of operating procedures, lack of adequate equipment and materials and the lack of capacity occur dealys in the work.

2) Transportation of work items - Transportation in the company is an inseparable part of the production process and during the work process causing unnecessary movement of people and raw material. Transportation is generated by poor organization at the workplace and the existence of several interphase warehouses.

3) The movement of employees -In SMEs, in the process of individual and small batch production, the workplace is not prepared, and the employee has frequent interruptions, i.e.. carries out useless work - Unnecessary interruptions during the working hours occur by the employee who has to move outside the workplace in order prepare yourself : documentation, materials or tools [31]. While employee prepares yourself for work, it is not carried out any kind of work at his workplace, lower production occurs in activities caused by delal - non-productive time [6]. Key factors for the occurrence of unnecessary movements are: improper work methods, lack of organization in the workplace or poor work organization, bad arrangement of work positions in the company, an inconsistent working methods, etc. [31].

4) Inventory - Inventories during manufacturing process include: raw materials, unfinished production or finished products . Unfortunately, inventories require additional handling, documents, space and costs. The main reasons for creating inventories in SMEs are: not sufficiently good relations with suppliers/vendors, an unbalanced production flow of business operations , inaccurate predictions of customer needs, but all in order to defend against changes in the market[32].

5) Production of defective parts - Production of defective parts or "spoilage" represents an inadequate implementation of business processes, insufficient training of employees or the lack of standardized procedures. In production of SMEs, There are losses at the output of final product that may be in the form of: scarp, pieces with defects, broken tools, ect.

6) Poor product design- Poor design of products includes too many processing steps, a to u which significantly complicates construction and and wherein is used amore resources.

7) Human resources- the word is actually about not exploited the human potential that represents a new and very important category [33]. It occurs due to insufficient or incomplete intellectual capacity utilization of all employees or due to lack of adequate intellectual capacity in the company. Managers of in SMEs need to properly schedules labor force and to invest more in their training. The intellectual capital represents the knowledge, experience, expertise, ability and skills of to enterprises to achieve better results and provide better service. [34]
8) Control - In companies where everything is going fast, it is difficult to take time to overcome something well and completely [35]. For working place during the production process is very important function of "self-control" performed by employees: through control of parts and components to the final inspection of final product [36].

\section{LC IN TRANSMITTER REALIZATION}

As an example for the improvement of production processes and implementation of LC, will serve local company with a small batch of transmitters. Company IHTM-CM appears on the domestic market as the only manufacturer of sensors and electronic pressure transducers and temperature. In Fig. 2, is given a photographic representation of the pressure transmitterwhich is realized on basis of analysis and application of LC.

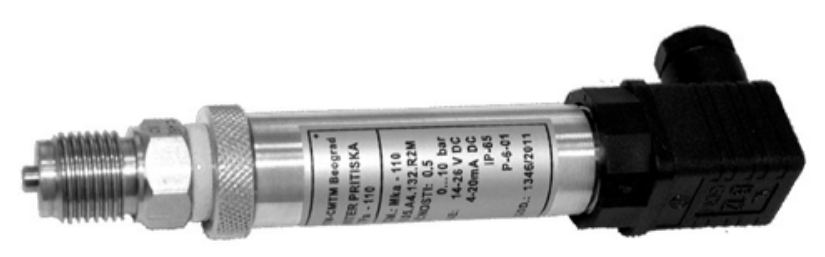

Fig. 2. Pressure transmitter, $\mathrm{TPa} / \mathrm{r}-110$

A pressure transmitter is designed to be modular design, i.e. consists of the following modules. (see Fig. 3): 1) pressure transducer, 2) metal casing in which is set an electronic block and 3) electrical connector .

The modularity of in the realization of the transmitter represents general concept describing extent to which can be independent components of system and be recombined. In this way, the system enables the connection of components or prohibits interference and synchronization of components [37]. Modules are linked together can give a new product. Just from this standpoint, transmitter modules enable application of renewable production process through LC's implementation.

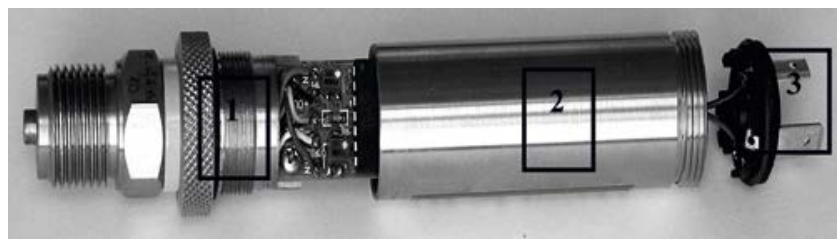

Fig. 3. Pressure transmitter modules, TPa / r-110

Electronic box consists of the following elements (see Fig. 3): 1) of electronics carrier connected to the pressure transducers, and 2) of the protective cover. On the electronics carrier attaches electronics. It serves to connect the transducers with electronics and electronics connector.

The protective cover of electronics box has a function to protect from an external influences, and also to strengthen the entire structure. Complete standard electronics box is made of aluminum-alloy Al.Cu5.Mg1.55. 


\section{AN ALGORITHM FOR IMPROVING} TRANSMITTER MANUFACTURING APPLYING LC

There are many losses in the production of pressure transmitters. An analysis is performed and algorithm is given for improving production but only on the level of manufacturing, in this paper. (see Fig. 4).

By algorithms are analyzed the losses that occur in:

1. Motion of employees - It is important to define proper movement of employees in IHTM-CMT. Specifically, in manufacturing process, there is open workplace or movement of employees/walk around the workplace that causes looking for an appropriate tools or materials which are not in its place or out of reach.

2. Improvement or reducing the observed losses implies structuring of closed type workplace. In such environment, the employee is always in his workplace, and all documents, tools and materials are submitted to him.

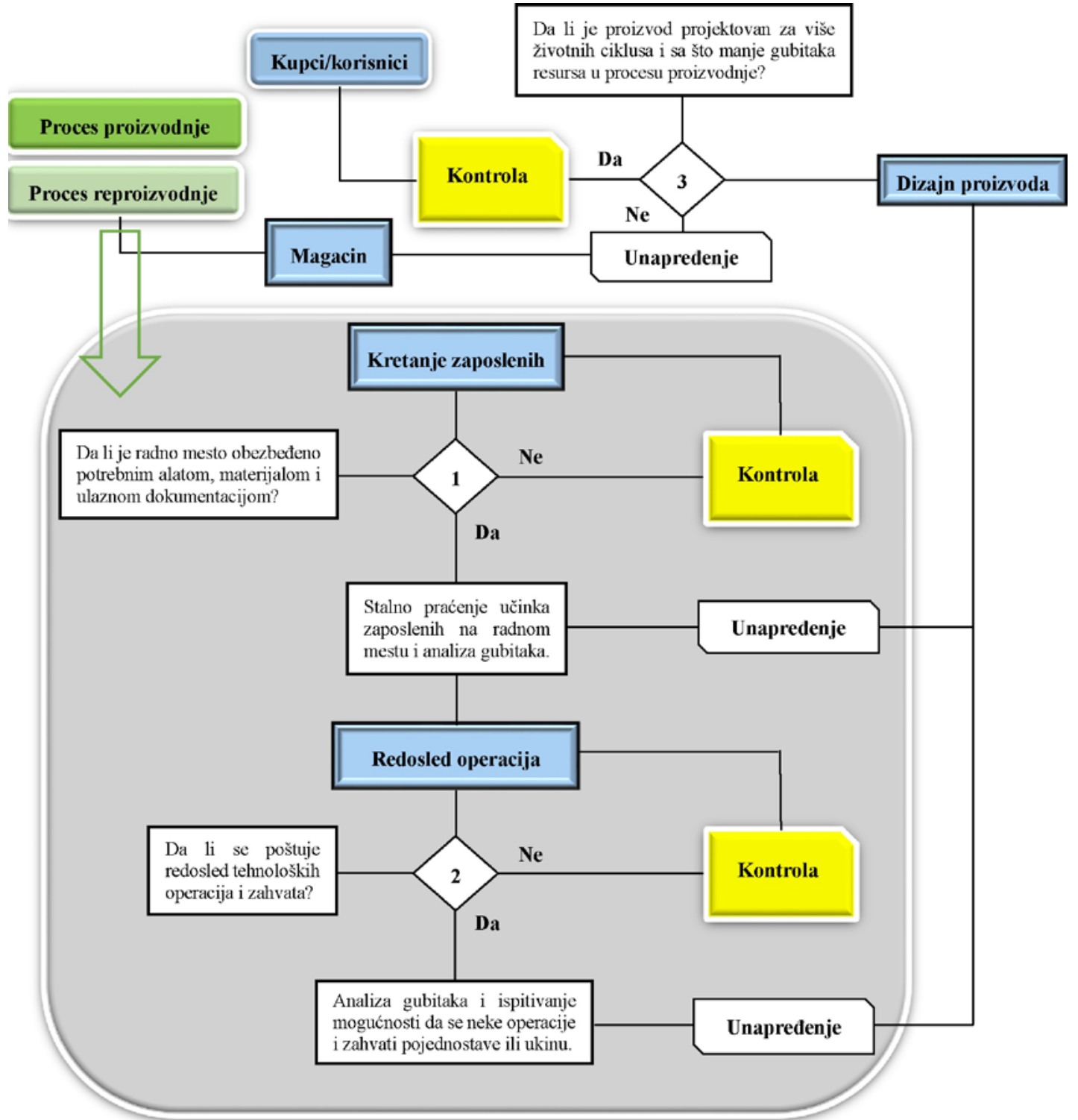

Fig. 4. An algorithm for improving transmitter manufacturing applying LC

5. Product design - product design is extremely important in the case of pressure transmitter which is related to business success. By analyzing the elements of LC, design to be a good design in itself

3. LC provides that the manufacturing process to be actively managed and controlled or to allow a steady stream of material and the effect of employees in the workplace. The objective of the company is to improve production time and to reduce unproductive time as much as possible.

4. The sequence of operations - in the production process of transmitters should perform the optimization of operations and proceless. The previous production of electronics box cover was done of full cylindrical pieces (Ø30x120mm), including more woodturning procedures. Processing had implied making tubular cover (see Fig. 2), considerable engagement of resources and high an irretrievably waste in the form of shavings. LC provides savings in materials, because instead of the full round pipe profiles now uses circular tube (Ø30x2x120mm). 
The cover and carrier of electronic box are designed that can be used again after the sensor failure. (pressure transmitters).

6. Customers/users - the role of customers/users is very important whish helps in in improving production process and developing new products. In this regard, it has come to easier approuch to electronics by installing standardized connectors in cooperation with the customers. Previous version of pressure transmitter has an axial connector (twice as expensive), while using LC comes to the use of the angle connectors (see Fig. 1). Angle connector is known as the "Hirschmann GDM," but most often referred to as the " mechanical" connector.

7. Inventory - types and dimensions of materials used in the preparation of pressure transmitters should be standardized before production process. The correct specification relieves the alternative dimensions of materials (purchase of larger diameter in order to get the requested one during the processing), reduces warehousing space, material waste and energy consumption in the processing.

8. Checks on - in order to improve production process of transmitters, it is necessary to constantly perform self-control at the workplace the permanent control of all parameters after each operation, control of finished pieces after the manufacturing process, control of measuring devices and instruments. It is very important to monitor issuing and control the entering and exiting documentations. In doing so, you should strive for reducing the excess (or waste) activities to a minimum, or to carry out a complete standardization of procedures at the workplace. (the sequence of standard operations which employees must respect, standard processing time for production).

\section{CONCLUSION}

The modern concept of business enterprise implies customer as a central figure with maximum savings of its resources. Identification and eliminate unnecessary activities allows to achieve the maximum quality of production processes. Any activity that absorbing resources complicates the production process and increases the product price and time of production.

Introducing of LC in a renewable production process which helps to assess situation in comanies with small batch type of production. LC provides a model for improving production process and communication with customers, as well as provide better performance on the market with the least losses (waste) in domestic compamies.

The transformation process in renewable production process receives feedback loop when a customer finds himself in the role of vendor. It introduces a new business philosophy in designing products for more life cycles, in order to reduce production losses, in this way [39].

The algorithm is designed on a level of production, but can also be applied at the level of other sectors of the company in company. Future researches should focus on the quality control of operations and more aggressive marketing activities in order to the entire LC get the right form.

We can conclude that if the LC is properly being implemented and conducted, in the company may occur: inventory reduction, reduction of processing time, increase product quality, increase employee efficiency, increase machine capacity utilization and space.

\section{ACKNOWLEDGEMENTS}

This paper has been created, partly, under the project TR-32008 by the Ministry of Education, Science and Technological Development, Republic of Serbia. We express special gratitude to colleague's $d r$. Philip Radovanović, who generously and professionally assists in the realization of this paper.

\section{REFERENCES}

[1] H. Schmitz, "Local enterprises in the global economy: Issues of governance and upgrading," Edward Elgar Publishing, (2004)

[2] M. J. Rosenblatt and H. L. Lee, "Economic production cycles with imperfect production processes," IIE Trans., Vol. 18(1), pp. 48-55, (1986)

[3] C. L. Anderson, "The Production Process: Inputs and Wastes',” J. Environ. Econ. Manag., Vol. 14(1), pp. 1-12, (1987)

[4] K. A. Mallidi, T. Paraskevopoulos and P. Paganelli, "Process modelling in small-medium enterprise networks,” Comput. Ind., Vol. 38(2), pp. 149-158, (1999)

[5] A. Rummler and P. Brache, "Improving performance: how to manage the white space on the organisation chart,” Geary A. 3rd. ed., ISBN: 978-1-118-14370-4, Published by Jossey Bass, (2013)

[6] http://file020.mylivepage.com/chunk20/5913442/2907/ udzbenik osnove proizvodnih i usluznih tehnologija.pdf; Radaković N., Ćosić I., Osnove proizvodnih i uslužnih tehnologija, radni materijal, FTN Novi Sad, N. Sad, (2007)

[7] B. Sladić, "Menadžment kvaliteta isporučilaca," Studio MS, Beograd, (2008)

[8] D. Maxwell and R. Van der Vorst, "Developing sustainable products and services, ” J. Clean. Prod., Vol. 11(8), pp. 883-895, (2003)

[9] H.Schmitz, "Collective efficiency: Growth path for small scale industry," J Dev. Stud., Vol. 31(4), pp. 529-566, (1995)

[10] J. Frijns and B. Van Vliet, "Small-scale industry and cleaner production strategies," World. Dev., Vol. 27(6), pp. 967-983, (1999)

[11] K. Hallberg, “A market-oriented strategy for small and medium scale enterprises,” (Vol. 63), World Bank Publications, (2000)

[12] D. A. Desai, “Cost of quality in small-and mediumsized enterprises: case of an Indian engineering 
company,” Prod. Plan. Control., Vol. 19(1), pp. 2534, (2008)

[13] E. Buffa, "Modern Production and Operations Management,” Willey, New York, (1980)

[14] M. Z. Hauschilda, J. Jeswietb and L. Altinga, "Design for Environment - Do We Get the Focus Right?," CIRP Ann. - Manuf. Techn., Vol. 53(1), pp. 1-4, (2004)

[15] I. Konstantaras and K. Skouri, "Lot sizing for a single product recovery system with variable setup numbers,” Eur. J. Oper. Res., Vol. 203(2), pp. 326335, (2010)

[16] J. S. Fargher, "Lean Manufacturing and Remanufacturing Implementation Tools,” Missouri Enterprise, University of Missouri, Rolla, MO, (2006)

[17] H. Kivanc, and M. S. Gupta, "Effect of Reusable Rate Variation on the Performance of Remanufacturing Systems," Sample papers from the Environmentally Conscious Manufacturing Conference, Boston, Massachusetts, USA, (2000)

[18] R. Giutinia and K. Gaudette, "Remanufacturing: The next great opportunity for boosting US productivity," Bus. Horizons, Vol. 46(6), pp. 41-48, (2003)

[19] A. Gehin, P. Zwolinski and D. Brissaud, “A tool to implement sustainable end-of-life strategies in the product development phase," J. Clean. Prod., Vol. 16(5), pp. 566-576, (2008)

[20] C. Karlsson and P. Åhlström,. “Assessing changes towards lean production,” Int. J. Oper. Prod. Man., Vol. 16(2), pp. 24-41, (1996)

[21] M. S. Bumgardner, "Benchmarking performance measurement and lean manufacturing in the rough," Forest. Prod. J., Vol. 56(6), pp.6, (2006)

[22] M. Rother and J. Shook, "Learning to see: value stream mapping to add value and eliminate muda," Lean Enterprise Institute, (2003).

[23] R. A. Inman and S. Mehra, "The transferability of just-in-time concepts to American small businesses," Interfaces, Vol. 20(2), pp. 30-37, (1990)

[24] B. Finch, “Japanese management techniques in small manufacturing companies: a strategy for implementation," Production and inventory management, Vol. 27(3), pp. 30-38, (1986)

[25] P. Achanga, E. Shehab, R. Roy, and G. Nelder, "Critical success factors for lean implementation within SMEs,” Journal of Manufacturing Technology Management, Vol. 17(4), pp. 460-471, (2006)
[26] J. F. Krafcik, "Comparative analysis of performance indicators at world auto assembly plants" $\mathrm{PhD}$ Thesis, Massachusetts Institute of Technology (USA), (1988)

[27] J.K. Liker, “The Toyota Way,” McGraw - Hill, New York, NY, pp. 1 - 159, (2004)

[28] P. Achanga, V. Taratoukhine, R. Roy and G. Nelder, "The application of lean manufacturing within small and medium sized enterprises”, Proceedings of International Conference on Manufacturing Research, Sheffield Hallam University, Sheffield, (2004)

[29] P. Mirzaei, "Lean production: Introduction and implementation barriers with SMEs in Sweden," (2011)

[30] R. Beňo, "Plytvanie (Muda) na pracovisku z hl'adiska ergonómie. Wasting (MUDA) in the workplace in terms of ergonomics," New Trends in Quality Management: 4th International Scientific SeminarTrnava: Alumni Press, pp.33-38. (2011).

[31] N. Mileusnić, "Stabilizacija i efikasnost proizvodnje: Organizacija procesa proizvodnje,” (Vol. 2), NIGRO Borba, Beograd, (1986)

[32] C. Loch and S. Kavadias, "Handbook of new product development management,” Routledge, (2007)

[33] J. Bicheno and M. Holweg, "The Lean Toolbox: The Essential Guide to Lean Transformation,” 4th edition, Buckingham, PICSIE Books, (2009)

[34] M. Šarčević, “Znanje kao ključni faktor konkurentske prednosti i unapređivanja inovativnosti,” Zbornik radova Ekonomskog fakulteta u Istočnom Sarajevu, Vol. 1(7), pp. 73-80, (2013)

[35] R. Senet,. “Kultura novog kapitalizma,” Arhipelag, Beograd, (2007)

[36] A. Šostar, "Savremeni sistem obezbeđivanja kvaliteta u proizvodnji,” Jugoslovenska naučna tribina Jugoslavija u razvoju, Tehnologija i razvoj, Beograd, (1989).

[37] M. Simon, “Design for Dismantling,” Professional Engineering, (1988)

[38] D. Cvetković and D. Marković, “Dizajn pakovanja,” Univerzitet Singidunum, Beograd, (2010)

[39] N. Nasr and M. Thurston, "Remanufacturing: A key enabler to sustainable product systems," Rochester Institute of Technology, (2006) 